\title{
Are interaction effects of various media advertising on firm performance super- additive or sub-additive?
}

\author{
Maqsood Iqbal Qureshi, a \\ ${ }^{a}$ Gulf University of Science and Technology, Kuwait
}

\begin{abstract}
Research Question: This study empirically investigates how various advertising media independently and jointly affect firms' financial performance.

Motivation: Advertising spending is one of the most significant budget items supporting marketing activities for most companies. However, in an era when media choices have become more numerous, firms remain uncertain about their media selection strategies and allocation of funds across various advertising media. There has been very limited effort to investigate interactive media advertising effects on firm performance and market valuation. Therefore, the primary motivation of this research is to examine individual and combined effects of various media advertising on firms' financial performance
\end{abstract}

Idea: This study examines various advertising media's individual as well as interaction effects on firm performance.

Data: Accounting data are downloaded from Datastream, except for advertising data. We obtained advertising data from AC Nielsen Meal. The resulting sample has 5165 firm years from 1998 to 2003.

Tools: To empirically test interactive media advertising effects on firm performance, this study employed a linear regression model in which earnings of firm i in year $t, E_{i t}$, can be expressed as function of tangible and intangible assets.

Findings: The results of this research suggest that individually, print and electronic media each have a positive and significant effect on earnings, but each form of media weakens the effectiveness of other respective media.

1 Corresponding author: Department of Accounting, Gulf University of Science and Technology, P.O Box 7207, Hawally 32093, Kuwait, email address: Qureshi.M@gust.edu.kw 
Contribution: Overall, the results of this study will help firms to make informed decisions to strategically integrate different media to maximize individual and combined effectiveness across all media types.

Keywords: advertising, electronic media, print media, earnings, television advertising, firm performance, value relevance, media types, market value, super-additive, sub-additive

\section{JEL Codes: M41}

\section{Introduction}

Firms consider advertising as one of the eminent budget items to support promotion activities that are important for their success in an era of increasing competition. To achieve and maintain advantage over competitors, firms allocate a large proportion of their budgets for advertising. Andras and Srinivasan (2003) argue that advertising and promotion outlays help firms to increase competitive advantage. Firms expect long-term economic gains or shareholder value from advertising expenditures.

To build brand awareness and promote brand image, firms disseminate advertisements to their target audiences through various media, such as newspapers, radio, cinemas, direct mail, television and the internet, among others. Sridhar et al. (2016) assert that firms spend enormous amounts on advertising every year but remain uncertain about appropriate allocation across media. Firms distribute advertising spending across various media outlets to enhance their sales, brand awareness, reach, and profitability. The proportion of firm budget spent on advertising varies across different media. Wurff et al. (2008) assert that each media differs in advertising characteristics and firms consider differential media effects when selecting advertising media. Wurff et al. (2008, p. 33) further contend that "Most advertising media consequently occupy considerably different niches on the advertising market, effectively claiming different resources." Shaver and Lacy (1999) find that intermedia advertising is competitive and assert that media differ in effectiveness for different types of advertising. The distribution of advertising outlays across media is one of the most important decisions that firms make.

The extant research provides evidence of the significant economic importance of advertising expenditure. Numerous studies provide evidence regarding the value relevance and asset value of advertising expenditures (e.g. Porter, 1976; Hirschey, 1982, 1985; Connolly and Hirschey, 1984; Hirschey and Weygand, 1985; Hirschey and Spencer, 1992; Chauvin and Hirschey, 1993; Lev and Sougiannis, 1996; Graham and Frankenberger, 2000; Notta and Oustapassidis, 2001; Shah et al., 2009; Joshi and Hanssens, 2010; Qureshi, 2015, 2017; Mcllkenny and Persaud, 2017, among others). An interesting trait of much of the academic research on the value relevance 
of advertising expenditure is that it has presumed uniform advertising effects and considered aggregate advertising expenditures at different points of time, overlooking potential variance in media advertising effects. A few studies (e.g. Hirschey, 1978, 1982; Rogers and Mullers, 1980; Yiannaka et al., 2002; Qureshi, 2015) have investigated the existence of differences in advertising effectiveness across different media and reported dissimilar effects of advertising disseminated through various media such as print and electronic media. While planning for advertising, firms face two types of choice: that is, which medium or combination of media to use (the inter-media choice) and where and how to deploy the advertising within the selected media (the intra-media choice) (Qureshi, 2015). These decisions are difficult but important, as they can have significant impacts on firms' financial performance and market value if differential media effects exist. While differential media advertising effects have been researched to some extent, there has been no effort to investigate interactive media advertising effects on firm performance and market valuation. Therefore, the primary motivation of this research is to investigate how different forms of media advertising independently and jointly affect firms' financial performance.

This study makes the following contributions to the literature. To the best of our knowledge, no study has yet explored interactive effects among various media advertising effects in the UK. This study adds to the scarce literature on the asset value of various advertising media expenditures by providing evidence of the relative performance effects of various advertising media along with their interactive effects on firm performance. The findings of this research will enhance understanding of the interactive effects among different advertising media on firms' financial performance and help firms to make informed decisions on various types of media advertising. An understanding of the interactive media effects will help firms to guide complex future decisions and to effectively manage their advertising spending, particularly in the distribution of advertising expenditures across different media. The findings of this study can help firms to exploit the effectiveness of their overall advertising budgets by strategically integrating different media to maximize individual and combined effectiveness across all media types.

The paper is organised as follows: the next section discusses the related literature. Section 3 presents a discussion on data, describes the research design and develops research hypotheses. Section 4 presents estimation results and section 5 concludes.

\section{Literature Review}

The extant research on advertising is diverse. There is a wide-ranging literature in marketing, economics, finance and accounting, which examines various aspects of advertising. For instance, there are numerous studies that are concerned with the impact of advertising on sales and profitability in marketing, competition, prices, 
consumption and profits, among other economic aspects in economics, and market value and financial performance in accounting and finance.

Very few studies focus on the relationships between various advertising media expenditure and firms' financial performance and market value. A survey of the extant literature did not reveal any articles that studied the impact of the interactive media advertising effects on firms' financial performance and market value in the UK. We review major previous research carried out in this area in accounting: this review is organized by impact of advertising on market value and performance.

An extensive body of literature provides empirical evidence on the impact of advertising expenditures on firms' market value. Hirschey (1982) investigates the market value effects of current advertising and research and development expenditures for a sample of 390 firm years over the period 1977. He finds significant positive market value effects of both advertising and research and development expenditures. He argues that advertising is long-lived and that it should be recorded as an intangible asset and amortised over its useful life.

Connolly and Hirschey (1984) estimate a valuation model for a sample of 390 firms from the 1977 Fortune 500 and document positive valuation effects of both research and development and advertising expenditures. They favour the 'intangible capital' view of research and development and advertising expenditures. Similarly, Hirschey and Weygandt (1985) and Hirschey (1985) also find a significant and positive association between the market value of firms and both research and development and advertising expenditures. Hirschey and Weygandt (1985) suggest that these expenditures should be capitalised and then amortised rather than given the current expense treatment.

In another study, Chauvin and Hirschey (1993) examine the influence of both advertising and research and development expenditures on the market value of the firm for a US sample over the period 1988-1990. Their results support that both advertising and research and development expenditures have positive, large and consistent influences on firm value and give rise to intangible capital.

However, contrary to the above results, Bublitz and Ettredge (1989) only find evidence of longevity for research and development and not for advertising expenditures, and argue for the treatment of the latter as an expense. Similarly, other studies, such as Core et al. (2003) and Erickson and Jacobson (1992), also find no effect of advertising expenditures on market value. Han and Manry (2004), for a Korean firm sample, report a negative association between advertising expenditures and stock prices. They argue that advertising expenditures do not represent future economic benefits, as these economic benefits expire in the current period. 
In the recent past, studies such as Qureshi $(2007,2015)$ and Shah et al. (2009) have used valuation models to examine the relation between market value and advertising expenditures in UK firms. Qureshi (2007) and Shah et al. (2009), using UK data and valuation models, report a significant positive relation between firm market value and advertising expenditures. Both studies support a durable effect of advertising expenditures on market value. In another study, Qureshi (2015) splits total advertising expenditures into various types of media advertising and examines the relations between various advertising media spending and market value in UK firms. Qureshi (2015) reports a positive and significant association between market value and various media advertising expenditures.

In their study, McIlkenny and Persaud (2017) examine the value relevance of voluntary disclosure of advertising expenditure by Canadian firms over the period 2007 to 2014. They note a positive association between market value and advertising expenditure for discloser firms and conclude that advertising expenditures are value relevant.

Various studies relate advertising expenditures to firms' profitability or sales. In his study, Abdel-Khalik (1975) examines the effects of advertising expenditures on sales revenues by employing a sample of firms from the food, auto, tobacco, soap and cleaners, and drugs and cosmetics industries for the period from 1955 to 1973 . He reports long-lived effects of advertising expenditures on sales only in the food, drug and cosmetic industries.

Seldom and Jung (1995) study the durability of advertising effects on consumption by using personal consumption and advertising data for the period 1947-1988. Their findings show that advertising effects linger for nine years but they do not find precise reasons for this.

Yiannaka et al. (2002), for a sample of firms in the Greek processed meat sector, find total advertising to be an important determinant of sales. However, they find that advertising effectiveness varies with advertising content and media used. They find that the effect of print media advertising (newspapers and magazines) on sales is more significant than the effects of both TV and radio advertising.

In contrast to the above research, studies such as Boyd and Seldon (1990), Seldon and Doroodian (1989) and Kwoka (1993), among others, report short-term advertising effects on sales. Shah and Akbar (2008) claim that the correlation between advertising and sales is not straightforward, and assert that "While advertising might have an impact on sales, there is also a possible effect of sales on advertising... This simultaneity of cause and effect further complicates the problem of a meaningful relationship between advertising and sales."

Studies such as Comanor and Wilson (1967), Weiss (1969), Porter (1976), Hirschey (1978), Demsetz (1979), Lev and Sougiannis (1996), Graham and Frankenberger (2000), Notta and Oustapassidis (2001) and Sridhar et al. (2016) provide evidence 
of the impact of advertising expenditures on firm performance. Comanor and Wilson (1967), for their sample of 41 consumer goods industries over the period 1954-57, report a significant positive impact of advertising on profit rates, which is a measure of market performance. Porter (1976) provides evidence that electronic and print media advertising have different implications for market performance, and finds that television advertising has a significantly greater impact on profitability compared to other types of advertising.

In another study, Hirschey (1978) reports a positive correlation between overall advertising and profitability. However, Hirschey (1978) finds significantly greater positive effect of television advertising on profitability than advertising in general. Lev and Sougiannis (1996) report that, for their sample, over a period of sixteen years through 1975 to 1991, advertising expenditure is correlated with an operating income increase.

Graham and Frankenberger (2000) use a sample of 320 US firms and report that changes in advertising expenditures are significantly associated with the firms' earnings and market values.

Notta and Oustapassidis (2001) examine the asset value of advertising for television, radio, magazine and newspapers for 350 food manufacturing firms. They show that only television advertising positively affects profitability.

Sridhar et al. (2016), using 12 years of data for 662 manufacturing firms, study the joint effects of national-reginal, national-online and regional-online advertising outlays on firm performance. They report positive and significant effects of national, regional and online advertising on firm performance. However, they note that each of the three types of media advertising weakens the performance impact on firm performance of the respective other two media types and report a negative interaction effect.

Tackx et al. (2017) examine whether advertising has a positive or a negative impact on profits. They use a sample of the top 500 brands of established companies in the world during the period 2008-2012 and find that advertising expenditures have no significant impact on profitability.

Shah et al. (2019) use UK firms' data over the period from 1997 to 2013 to study the relationship between advertising expenditures and firm performance. They report a significant positive association between advertising expenditures and firms' future earnings and market value. Contrary to the above, Reekie and Bhoyrub (1981) are unable to find a significant relationship between advertising and profitability. 


\section{Data, Research Strategies and Model Development Hypotheses}

We examine how various advertising media affect firm performance. The evidence in the extant literature - for example, Hirschey (1978), Notta and Oustapassidis (2001), Qureshi (2015) and Sridhar et al. (2016) - suggests that various advertising media outlays positively influence firm performance individually. Thus, we expect a positive impact on firm performance from different measures of media advertising expenditures, namely print media advertising, electronic media advertising, press advertising and television advertising. Existing literature provides limited and conflicting evidence on various media interaction effects and it is unclear whether positive or negative interaction effects should be expected between print and electronic media advertising and press and television advertising.

Advertising media expenditures variables APit and AEit in equation 3 and APRit, ATVit and ARDit in equation 4 are expense items. If the expenditures represented by these variables are expected to provide future economic benefits, their coefficients $\beta 4, \beta 5, \beta 6, \beta 40, \beta 50$ and $\beta 60$ should be greater than 0 . To test for this, we form the following hypotheses:
H01: $\quad$ B4 $=0$
H02: $\quad$ $\quad 35=0$
H03: $\quad \beta 6=0$
H04: $\quad B 40=0$
H05: $\quad B 50=0$
H06: $\quad B 60=0$

\subsection{Model Development, Research Strategies and Sample}

To empirically test interactive media advertising effects on firm performance, we estimate various models. The baseline model used for this study is an extended version of that developed by Lev and Sougiannis (1996) and Graham and Frankenberger (2000) in which the earnings of firm $i$ in year $t, E_{i t}$, can be expressed as function of tangible, $\mathrm{TA}_{\mathrm{it}}$ and intangible assets, $\mathrm{IA}_{\mathrm{it}}$.

$\mathrm{E}_{\mathrm{it}}=\mathrm{g}\left(\mathrm{TA}_{\mathrm{it}}, \mathrm{IA}_{\mathrm{it}}\right)$

This study develops the following equation by introducing intangible advertising expenses (A), research and development expenditures (RD) and goodwill (G) in equation (1):

$E_{i t}=g\left(T A_{i t}, G_{i t}, R D_{i t}, A_{i t}\right)$

To find the individual and joint impact of print and electronic media on firm performance, we operationalize equation 2 as follows:

Eit $=\beta 0+\beta 1$ Bit $+\beta 2$ RDit $+\beta 3$ Git $+\beta 4$ APit $+\beta 5$ AEit $+\beta 6$ APit $x$ AEit $+\xi$ 
Where E is earnings, B is book value, G is goodwill, RD is research and development, AP is press media advertising expenditures, AE is electronic media advertising expenditures and $\xi$ is an error term. The AP variable comprises newspapers, magazines and outdoor advertising expenditures, and the $\mathrm{AE}$ variable comprises television, radio and cinema advertising expenditures. The AP x AE variable represents the interaction between print and electronic media.

We also test the individual and joint impacts of newspapers and television advertising on firm performance and estimate the following equation:

Eit $=\beta 0+\beta 1$ Bit $+\beta 2$ RDit $+\beta 3$ Git $+\beta 40$ APRit $+\beta 50$ ATVit $+\beta 60$ APRit $x$ ATVit + $\xi \quad(4)$

Where APR represents press advertising expenditures, ATV represents television advertising expenditures and APR x ATV represents the interaction between press and television.

We estimate models 3 and 4 with the OLS regression approach for pooled data for the period from 1998 to 2003. An analysis of the validity of the econometric specification and related assumptions underlying the statistical model denotes that the results are robust and consistent with these assumptions. To manage the heteroscedasticity problem, deflation has been applied, and number of shares (OS) is used as deflator. An examination of the correlation matrixes presented in Table 1 suggests that heteroscedasticity is not a problem.

Table 1. Correlation Matrix

I. Press and Television Media Advertising Expenditures

\begin{tabular}{lccccrr}
\hline & B & RD & G & APR & ATV & APRXATV \\
\hline B & 1 & & & & & \\
RD & 0.012 & 1 & & & & \\
G & -0.012 & $0.100^{* *}$ & 1 & & & \\
APR & 0.002 & -0.017 & -0.025 & 1 & & \\
ATV & $0.033^{*}$ & -0.003 & -0.013 & $0.662^{* *}$ & 1 & \\
APRXATV & 0.002 & -0.010 & -0.016 & $0.806^{* *}$ & $0.765^{* *}$ & 1 \\
\hline
\end{tabular}

$*$, and ${ }^{* *}$, significant at the 0.05 , and 0.01 level respectively.

II. Press and Electronic Media Advertising Expenditures

\begin{tabular}{lcccccc}
\hline & B & RD & G & AP & AE & APXAE \\
\hline B & 1 & & & & & \\
RD & 0.012 & 1 & & & & \\
G & -0.012 & $0.100^{* *}$ & 1 & & & \\
AP & 0.008 & -0.013 & -0.023 & 1 &
\end{tabular}

Vol. 20, No. 2 


\begin{tabular}{lcccccc} 
AE & $0.035^{*}$ & -0.006 & -0.012 & $0.691^{* *}$ & 1 & \\
APXAE & 0.005 & -0.008 & -0.016 & $0.845^{* *}$ & $0.742^{* *}$ & 1 \\
\hline
\end{tabular}

$*$, and **, significant at the 0.05 , and 0.01 level respectively.

The sample includes firms listed on the London Stock Exchange (LSE) from 1998 to 2003: a period during which firms were allowed under FRS 1o to capitalize goodwill. Accounting data are downloaded from Datastream, except for advertising data. We obtained advertising data from AC Nielsen Meal. To be included in the sample, all essential accounting must be available. Also, the sample is restricted to firms with positive book value and earnings. The resulting sample has 5165 firm years from 1998 to 2003, inclusive. For the sample, the means and medians of the main independent variables are reported in Table 2.

Table 2. Descriptive statistics

I. Press and Television Media Advertising Expenditures

\begin{tabular}{|c|c|c|c|c|c|c|c|}
\hline & $\mathbf{E}$ & B & RD & $\mathbf{G}$ & APR & ATV & APRXATV \\
\hline Mean & 0.21 & 1.60 & 0.02 & 0.13 & 0.002 & 0.002 & 0.0001 \\
\hline Median & 0.13 & 0.78 & 0.00 & 0.00 & 0.00 & 0.00 & 0.00 \\
\hline Maximum & 5.77 & 185.14 & 2.71 & 6.65 & 0.26 & 0.33 & 0.07 \\
\hline Minimum & 0.00016 & 0.00038 & 0.00 & -0.06 & 0.00 & 0.00 & 0.00 \\
\hline Std.Dev. & 0.29 & 4.58 & 0.09 & 0.35 & 0.011 & 0.014 & 0.002 \\
\hline \multirow[t]{2}{*}{ Observations } & & 5165 & & & & 5165 & 5165 \\
\hline & 5165 & & 5165 & 5165 & 5165 & & \\
\hline \multirow[t]{2}{*}{ II. } & Press & nd Electro & nic Medi & a Advert & ising Exp & enditures & \\
\hline & $\mathbf{E}$ & B & RD & $\mathbf{G}$ & $\mathbf{A P}$ & $\mathbf{A E}$ & APXAE \\
\hline Mean & 0.21 & 1.60 & 0.02 & 0.13 & 0.002 & 0.002 & 0.0001 \\
\hline Median & 0.13 & 0.78 & 0.00 & 0.00 & 0.00 & 0.00 & 0.00 \\
\hline Maximum & 5.77 & 185.14 & 2.71 & 6.65 & 0.40 & 0.33 & 0.09 \\
\hline Minimum & 0.00016 & 0.00038 & 0.00 & -0.06 & 0.00 & 0.00 & 0.00 \\
\hline \multirow{2}{*}{$\begin{array}{l}\text { Std.Dev. } \\
\text { Observations }\end{array}$} & 0.29 & 4.58 & 0.09 & 0.35 & 0.013 & 0.015 & 0.002 \\
\hline & 5165 & 5165 & 5165 & 5165 & 5165 & 5165 & 5165 \\
\hline
\end{tabular}

\subsection{Variable Definition and Measurement}

Earnings, E, are measured as profit for the financial year as reported in the financial statements and adjusted for advertising and research and development expenditures. Book Value, B, is measured as the sum of shareholder equity capital and reserves. Research and Development expenditures, RD, are measured as RD expense recognized in the income statement. Goodwill, G, is measured as excess cost over the fair market value of the net assets purchased. Press Media advertising expenditures, AP, comprise newspapers, magazines and outdoor advertising expenditures. Electronic Media advertising expenditures, AE, comprise television, radio and cinema advertising expenditures. Press advertising expenditures, APR, 
comprise newspaper advertising expenditures. Television advertising expenditures, ATV, comprise television advertising expenditures.

\section{Empirical Results}

The results from the OLS regression runs of the two models 3 and 4 are presented in Tables 3 and 4.

Table 3. Model 3 Estimation Results -Pooled Sample (1998-2003)

Eit $=0.11+0.03$ Bit+ 1.11 RDit + 0.07 Git + 1.78 APit + 2.69 AEit -9.53 APit X AEit $+\xi$

\begin{tabular}{lrrrrrrrrr}
\hline Variable & \multicolumn{1}{c}{ Constant } & \multicolumn{1}{l}{ B } & \multicolumn{1}{l}{ RD } & G & \multicolumn{1}{l}{ AP } & AE & APXAE & $\mathbf{R}^{2}$ & Cases \\
\hline Pooled & 0.11 & 0.03 & 1.11 & 0.07 & 1.78 & 2.69 & -9.53 & 0.42 & 5165 \\
(p value) & $(0.00)$ & $(0.00)$ & $(0.00)$ & $(0.00)$ & $(0.00)$ & $(0.00)$ & $(0.00)$ & & \\
\hline
\end{tabular}

Table 4. Model 4 Estimation Results -Pooled Sample (1998-2003)

Eit $=0.11+0.03 B i t+1.11$ RDit+0.07Git+1.79APRit+2.67ATVit-9.24 APRit X ATVit+ $\xi$

\begin{tabular}{lrrrrrrrrr}
\hline Variable & Constant & \multicolumn{1}{l}{ B } & \multicolumn{1}{l}{ RD } & G & APR & ATV & APRXATV & R $^{2}$ & Cases \\
\hline Pooled (p & 0.11 & 0.03 & 1.11 & 0.07 & 1.79 & 2.67 & -9.24 & 0.42 & 5165 \\
value) & $(0.00)$ & $(0.00)$ & $(0.00)$ & $(0.00)$ & $(0.00)$ & $(0.00)$ & $(0.01)$ & & \\
\hline
\end{tabular}

Table 3 presents pooled regression 3 results. The results indicate that our two focal variables of interest - print media (AP) and electronic media (AE) - have significant positive effects on firm performance. We can reject null hypotheses H01 and H02. The AP coefficient (B4) is 1.78 ( $\mathrm{p}<.001)$ and the AE coefficient (B5) is 2.69 (p < $.001)$. These results are consistent with findings from previous research (e.g. Hirschey, 1978; Notta and Oustapassidis, 2001; Qureshi, 2015, 2019; Sridhar et al., 2016), which suggest that various advertising media outlays individually influence firm performance and valuation positively. Regarding interaction effects between print and electronic media, the estimates in regression 3 suggest a negative and significant interaction between print and electronic advertising. The AP x AE variable coefficient $(B 6)$ is $-9.53(\mathrm{p}<.001)$. The negative coefficient indicates subadditive effects on firm performance. These results are in line with previous research outcomes (e.g. Sridhar et al., 2016). These results suggest that each of print and electronic media exert positive effects on firm earnings, but they each weaken the force of the other. The adjusted $\mathrm{R}^{2}$ is 0.42 .

Our other control variables in regression 3, namely book value (B), research and development (RD) and goodwill $(\mathrm{G})$, explain variation in firm performance. All of these three variables have significant positive impacts on earnings. These results 
confirm previous research findings (e.g. Qureshi, 2007, 2015; Shah et al., 2009, 2019, among others).

Table 4 presents the pooled regression 4 results. The coefficients on APR (1.79) and ATV (2.67) are significantly greater than $0(\mathrm{p}<.001)$, suggesting that the impact of both press and television advertising expenditures individually on firm performance is positive and significant. These results do not provide support for hypotheses $\mathrm{H} 4$ and $\mathrm{H} 5$. The results show significant negative interaction effects between press and television advertising. The coefficient ( $(60)$ on APR x ATV is $-9.24(\mathrm{p}<.001)$. The two advertising media - press and television - independently have positive and significant effects on earnings, but they weaken each other's effectiveness. This identifies that the interaction effects of various types of media advertising on firm performance are sub-additive and not super-additive. The possible reason for these negative interaction effects may be weak strategic integration across media. Prior research, such as the works of Naik et.al. (2005) and Sridhar and Sriram (2015), has provided support for sub-additive interactive effects. In their study, Naik et al. (2005) find negative interaction effects between advertising and promotion activities in detergents market. They assert that "...when advertising and promotion are used together, their impact on brand shares is attenuated."

The results for the other control variables for regression 4 are consistent with prior expectations from extant research. The adjusted $R^{2}$ is 0.42 .

These results are in line with those of Sridhar et al. (2016), who investigate interaction effects among national, regional and online media and report negative interaction effects among these media vehicles. In summary, the results from estimating equations 3 and 4 suggest that interactive effects among various media on firm performance are sub-additive. To avoid these sub-additive effects and to attain super-additive benefits among chosen media, Sridhar et al. (2016) suggest that firms should better integrate their media portfolios and build a cohesive message and narrative across all media types.

\section{Summary}

Firms allocate large amounts of their budgets for advertising expenditures, but are uncertain about the effective allocation of these funds among various media (e.g. print, electronic, and online) to maximize the effectiveness of their budgets. This study empirically examines individual and combined effects of various media advertising on firms' financial performance by using a large sample of UK listed firms for the period from 1998 to 2003. Overall, our results suggest that various measures of advertising media, such as press, television, print and electronic media, individually exert positive significant effects on firm performance, but they weaken each other's effectiveness. We noted interactive effects between media types to be negative and significant. This negative and significant interaction between different 
media types identifies sub-additive joint effects. Firms should carefully observe these sub-additive effects and try to minimise them. Failing to control these subadditive effects could diminish the performance of media spending and impact firms' financial performance negatively. To achieve positive interaction effects, firms need to improve strategic integration across media.

This study provides empirical evidence of sub-additive joint effects of press, television and print, and electronic media. The results of this study, in an era when media choices have become more numerous, will help managers in the selection of media and media strategies to obtain the objectives the company is pursuing. We have only included major advertising media - i.e. press, television and print, and electronic media - in our analysis. Future research can extend this by considering more advertising media, such as internet/online advertising.

\section{References}

Abdel-Khalik, A. R. (1975) "Advertising effectiveness and accounting policies", The Accounting Review, vol. 50 (supplement): 657-670

Andras, T. L. \& Srinivasan, S.S. (2003) "Advertising intensity and R\&D intensity differences across industries and their impact on firm's performance", International Journal of Business and Economics, vol. 2, no. 2: 81-90

Boyd, R. \& Seldon, B. J. (1990) "The fleeting effect of advertising: Empirical evidence from a case study", Economics Letters, vol. 34, no. 4: 375-379

Bublitz, B. \& Ettredge, M. (1989) "The information in discretionary outlays: Advertising, research and development", The Accounting Review, vol. lxiv, no. $1: 108-124$

Chauvin, K. W. \& Hirschey, M. (1993) "Advertising, R\&D expenditures and the market value of firms", Financial Management, vol. 22, no. 4: 128-140

Comanor, W. S. \& Wilson, T. A. (1967) "Advertising market structure and performance", The Review of Economics and Statistics, vol. 49, no. 4: 423-440

Connolly, R. A. \& Hirschey, M. (1984) "R\&D, market structure and profits: A value-based approach", The Review of Economic and Statistics, vol. 66, no. 4: 682-686

Core, J. E., Guay, W.R. \& Buskirk, A.V. (2003) "Market valuations in the new economy: an investigation of what has changed", Journal of Accounting and Economics, vol. 34, no. 1-3: 43-67

Demsetz, H. (1979) "Accounting for advertising as a barrier to entry", The Journal of Business, vol. 52, no. 3: 345-360

Erickson, G. \& Jacobson, R. (1992) "Gaining comparative advantage through discretionary expenditures: The returns to R\&D and advertising", Management Science, vol. 38, no. 9: 1264-1279 
Graham, R. C. Jr. \& Frankenberger, K. D. (2000) "The contribution of changes in advertising expenditures to earnings and market values", Journal of Business Research, vol. 50, no. 2: 149-155

Han, B.H. \& Manry, D. (2004) "The value-relevance of R\&D and advertising expenditures: evidence from Korea”, International Journal of Accounting, vol. 39, no. 2: $155-173$

Hirschey, M. (1978) "Television advertising and profitability", Economics Letters, vol. 1 , no. $3: 259-264$

Hirschey, M. (1982) "Intangible capital aspects of advertising and R\&D expenditures", The Journal of Industrial Economics, vol. 30, no. 4: 375-390

Hirschey, M. (1985) 'Market structure and market value", Journal of Business, vol.58, no. 1: $89-98$

Hirschey, M. \& Spencer, R. S. (1992) "Size effects in the market valuation of fundamental factors", Financial Analysts Journal, vo. 48, no. 2: 91-95

Hirschey, M. \& Weygandt, J. J. (1985) "Amortisation policy for advertising and research and development expenditures", Journal of Accounting Research, vol. 23 , no. 1: 326-335

Joshi, A. \& Hanssens, D. M. (2010) "The direct and indirect effects of advertising spending on firm value", Journal of Marketing, vol. 74, no. 10: 20-33

Kwoka, J.E. Jr. (1993) "The sales and competitive effects of styling and advertising practices in the U.S. auto industry", Review of Economics and Statistics, vol.75, no. 4: 649-656

Lev, B. \& Sougiannis, T. (1996) "The capitalization, amortization, and value relevance of R\&D”, Journal of Accounting and Economics, vol. 21, no. 1: 107-138

McIlkenny, P. \& Persaud, A. (2017) "Value relevance of the voluntary disclosure of advertising expenditure: evidence from Canada", Int. J. Accounting and Finance, vol. 7, no. 3: $185-208$

Naik, P. A., Raman, K. \& Winer, R. S. (2005) "Planning marketing-mix strategies in the presence of interaction effects", Marketing Science, vol. 24, no. 1: 25-34

Notta, O. \& Oustapassidis, K. (2001) "Profitability and media advertising in greek food manufacturing industries", Review of Industrial Organization, vol. 18, no. $1: 115-126$

Porter, M. E. (1976) "Interbrand choice, media mix and market performance", The American Economic Review, vol. 66, no. 2: 398-406

Qureshi, M. I. (2007) "Asset value of UK firms advertising expenditures". Global Journal of International Business Research, vol. 1, no. 1:12-23

Qureshi, M. I. (2015) "Valuation of various media advertising expenditures - UK perspective". The International Journal of Accounting, Auditing and Performance Evaluation, vol. 11, no. 1: 1-13

Qureshi, M. I. (2017) "The value relevance of intangibles: some evidence on industry sector, firm performance and size effects". The International Journal of Accounting, Auditing and Performance Evaluation, vol. 13, no. 3: 293-307 
Reekie, W.D. \& Bhoyrub, P. (1981) "Profitability and intangible assets: another look at advertising and entry barriers", Applied Economics, vol. 13, no. 1: 99-107

Rogers, R. T., \& Mueller, W. F. (1980) "The role of advertising in changing concentration of manufacturing industries', The Review of Economics and Statistics, vol. 62, no. 1: 89-96

Seldon, B. J. \& Doroodian, K. (1989) "A simulation model of cigarette advertising: Effects on demand and industry response to public policy', The Review of Economics and Statistics, vol. 71, no. 4: 673-677

Seldon, B.J. \& Jung, C. (1995) "The length of the effects of aggregate advertising on aggregate consumption", Economics Letters, vol. 48, no. 2: 207-211

Shah, S.Z.A, Stark, A. W. \& Akbar, S. (2009) "The value relevance of major media advertising expenditure: some UK evidence", The International Journal of Accounting, vol. 44, no. 2: 187 - 206

Shah, Z.A., Akbar, S., Ahmad, S. \& Stark, A., W. (2019) "Advertising, earnings prediction and market value: An analysis of persistent UK advertisers", British Journal of Management, Accepted manuscript forthcoming.

Shah, Z.A. \& Akbar, S. (2008) "Value relevance of advertising expenditure: A review of the literature", International Journal of Management Reviews, vol. 10 , no. $4: 301-325$

Shaver, M. A., \& Lacy, S. (1999) "The impact of intermedia and newspaper competition on advertising linage in daily newspapers", Journalism and Mass Communication Quarterly, vol. 76, no. 4: 729-744

Sougiannis, T. (1994) "The accounting based valuation of corporate R\&D" Accounting Review, vol. 69, no. 1: 44-68

Sridhar, S., Germann, F., Kang, C. \& Grewal, R. (2016) "Relating online, regional, and national advertising to firm value", Journal of Marketing, vol. 80, no. 4: 39-55

Sridhar, S. and Sriram S. (2015) "Is online newspaper advertising cannibalizing print advertising?" Quantitative Marketing and Economics, vol. 13, no. 4: 283-318

Tackx, K., Rothenberger, S. \& Verdin, P. (2017) "Is advertising for losers? An empirical study from a value creation and value capturing perspective", European Management Journal, vol. 35, no. 3: 327-335

Weiss, L. W. (1969) 'Advertising, profits, and corporate taxes', The Review of Economics and statistics, vol. 51, no. 4: 421-430

Wurff, R., Bakker, P. \& Picard, G. R. (2008) "Economic growth and advertising expenditures in different media in different countries", Journal of Media Economics, vol. 21, no. 1: 28-52

Yiannaka, A., Giannakas, K. \& Tran, K. C. (2002) "Medium, message, and advertising effectiveness in the Greek processed meat industry', Applied Economics, vol. 34, no. 14: 1757-1763 